\title{
The Effect of Work Motivation and Work Discipline on Teachers' Performance
}

\author{
Dian Rizalini $^{\left.1^{*}\right)}$, Yasir Arafat ${ }^{2}$, Alhadi Yan Putra ${ }^{2}$ \\ ${ }^{1} S D$ Negeri 03 BPR Ranau Tengah \\ ${ }^{2}$ Universitas PGRI Palembang \\ *Corresponding author. E-mail: dianriza2019@gmail.com
}

\begin{abstract}
The purpose of this study was to determine the effect of work motivation and work discipline on the performance of elementary school teachers in BPR Ranau Tengah District, Oku Selatan Regency. This quantitative research with experimental methods, used questionnaires and observations for collecting the data. This study consisted of three variables (two independent variables: work motivation and work discipline, and one dependent variable: teachers' performance). From the results of this study it is known that there is an effect of work motivation (x1) on teachers performance (y). This is evidenced by the value of work motivation (15.609)> table (1.66055) and the significant value of work motivation $(0.00)<\mathrm{a}(0.05)$.
\end{abstract}

Keywords: Work motivation, Work Discipline, Teacher Performance.

\section{INTRODUCTION}

Education plays an important role in realizing the quality of human resources. Improving the quality of human resources is a process that cannot be separated from the process of improving education services carried out by teachers. The more qualified a teacher is, the better the development of students will be. The main task of the teacher is an indicator that will be used as a measurement of teacher performance in carrying out their duties [1].

The law of the Republic of Indonesia Number 14 of 2005 [2] concerning Teachers and Lecturers, article 1 paragraph (1) explains that: Teachers are professional educators with the main task of educating, training, guiding, teaching, directing, assessing and evaluating students in early childhood education, primary education, formal education, and secondary education. Teacher performance is an important thing because it shows what teachers have done in achieving educational goals in schools.

However, the reality in the field shows that there are still some teachers whose performance is not optimal [3], [4], [5]. Based on the writers' observations at elementary schools at BPR Ranau Tengah District, it is found that teachers who have low work motivation in teaching, their students' grades $60 \%$ do not reach the criterion of minimum score. Meanwhile, teachers who have high work motivation in teaching, the value of their students $60 \%$ reach the criterion of minimum score. Therefore, work motivation is a factor that plays an important role in the learning process.

A teacher must be able to transform information and learning to students. The main task of the teacher is not only to convey knowledge but to cultivate understanding so that students can learn independently. The ability to find on their own and learn on their own can be learned [6].

Many factors affect teacher performance, including adequate competence, a safe and healthy work environment, opportunities to develop knowledge, a sense of belonging, work motivation, work discipline and others [7]. Teacher performance, apart from being influenced by work motivation, can also be influenced by high work discipline [3], [8]. Moreover, the pandemic of covid19 also affects the anxiety of many people including teachers [9]. Thus schools that in the teaching and learning process foster discipline, will function as forming values and norms for students, attitudes and responsibilities for teachers, and self-control.

Work motivation is interrelated with teacher performance in a school, because work motivation can give a sense of appreciation to the teacher so that it fosters a sense of happiness in carrying out their work obligations which will be in line with improving teacher performance [3]. Teacher 
performance can be measured using pedagogical competence, professional competence, social competence, and personality competence. This is based on Permendikas RI No. 18 of 2007 explains that: There are four competencies as professional teachers, namely pedagogical competence, professional competence, social competence and personality competence. The competence that must be possessed by the teacher refers to teacher performance.

The series of activities at school is an effort to achieve the school's goals, so that all school organizational activities can be managed optimally. In order to achieve the goals, teacher performance must be improved. However, teacher performance can be influenced by several factors, namely motivation [3], training [8], discipline 10], and work environment [3]. Among the factors that affect teacher performance, this study focuses on the variables to be studied, namely work motivation, work discipline and teacher performance.

Work motivation is an impetus that grows from a person, both from within and from outside himself to do a job with high enthusiasm using his abilities and skills. The indicators of work motivation are: the need for existence needs is related to the physical existence of teachers such as food, clothing, salary, drinking, allowances and security of working conditions; Relationship needs, namely the satisfaction of interacting in the work environment; The need to develop themselves, improve abilities and self-potential related to teacher skills and abilities.

Motivation is a desire to do one's job well or to be encouraged by others to do one's job well in order to achieve one's goals. Wahjosumidjo [11] supports this viewpoint, stating that motivation as a psychological mechanism is influenced by both internal or intrinsic and external or extrinsic influences. The same can be said for the dimension of job motivation.

Teacher performance is a level of progress for a teacher on the results of his efforts to positively improve abilities in his work. The teacher performance indicators are as follows: Planning a learning program; Carry out learning; and Carry out learning evaluations.

Discipline is the awareness or willingness of a person to obey all applicable social rules and norms. Work discipline is a person's ability to regularly, diligently, continuously and work in accordance with applicable rules and does not violate predetermined rules. Work discipline has several goals: 1) To ensure teacher behavior is consistent with school rules, 2) To cultivate or maintain mutual respect and trust, 3) Discipline action can also help teachers to be more productive, 4) Effective disciplinary action can spur individual teachers to improve work performance (performance). It can be concluded that the teacher's lack of discipline in carrying out tasks, such as frequent arrivals late to school, indifference to students results in low student quality. Work discipline has a positive and significant effect on teacher performance [12].

The reality in the field about the performance of elementary school teachers in BPR Ranau Tengah District shows that there are some teachers who have a low tendency in terms of motivation and work discipline, such as teachers arriving late, often neglecting assignments, and not making lesson plans. If this is allowed, it will continue to decline, either directly or indirectly, which will affect teacher performance in the learning process. The above problem encourages the writer to examine "The Effect of Work Motivation and Work Discipline on the Performance of Elementary School Teachers ".

\section{METHODS}

This is a quantitative study with experimental methods [13], [14]. This study consisted of three variables in the form of two independent variables and one dependent variable. The independent variables in this study are work motivation and work discipline. Meanwhile, the dependent variable in this study was the performance of elementary school teachers in the District of BPR Ranau Tengah.

For collecting the data, observations and questionnaires were used [15]. This research was conducted by observing elementary school teachers in the District of BPR Ranau Tengah in the form of direct observation and data collection on the research object. The questionnaire consists of list of questions directly to the elementary school teachers in the District of BPR Ranau Tengah. The scale used is the Likert scale to measure attitudes, opinions and perceptions about social events or symptoms.

\section{RESULTS AND DISCUSSION}

Based on the research results, it is known that there is an effect of work motivation (X1) and work discipline (X2) on teacher performance (Y). This is evidenced by the value of Fcount (124.884)> Ftable (5.809) and the value of Fsig (0.000) $<\alpha(0.05)$. These results support the hypothesis proposed that there is an effect of work motivation and work discipline on teacher performance. The coefficient of determination (Adjust R Square) is 0.715, which implies that the influence of the independent variables (work motivation and work discipline) on the dependent variable (teacher performance) is $71.5 \%$, while the remaining $28.5 \%$ is influenced by the variables. others who were not examined in this study. Based on the research results, it shows that work motivation and work discipline have a 
significant effect on teacher performance. These results support the hypothesis that work motivation and work discipline have an effect on teacher performance.

The results of this study are consistent with the some previous studies mentioned above which show that work motivation and work discipline have an effect on teacher performance. Sukadi (2016) found that work motivation and work discipline on teacher performance obtained a regression equation: $\mathrm{Y}=$ $6.769+0.401 \mathrm{X} 1+0.275 \mathrm{X} 2$. The regression test obtained Fcount> Ftable or 137.168> 3.090 (5\% significance level) means that between work motivation and work discipline together have an effect on teacher performance. The $t$ test for work motivation variable obtained $\mathrm{t}$ count $>\mathrm{t}$ table or $4,872>1,985$ and for work discipline variable obtained $\mathrm{t}$ count $>\mathrm{t}$ table or $8,172>1,985(5 \%$ significance level). Both of these variables have a significant influence on the performance of teachers at MTs Al Huda Karangpandan.

However, the findings of this study contradict the research of Malik and Sriwidodo (2013) which concluded: in testing the one hypothesis the significance coefficient of the work motivation variable is 0.145 , the motivation variable does not have a significant effect on teacher performance. Testing the second hypothesis, the coefficient of significance for the discipline variable is 0.372 , then the discipline variable does not have a significant effect on teacher performance. Testing the third hypothesis, the coefficient of significance of the principal's leadership variable is 0.075 , then the principal's leadership variable does not have a significant effect on teacher performance. From the results of the absolute difference test, the principal's leadership does not moderate work motivation on teacher performance. Likewise, the leadership of the principal does not moderate discipline on teacher performance. The coefficient of determination test results obtained $\mathrm{R} 2$ of 0.310 , which means that the contribution of the influence of work motivation and discipline variables on teacher performance with leadership as a moderating variable is $31 \%$, the rest is influenced by other variables. So with work motivation and high work discipline, teacher performance will increase.

\section{CONCLUSION}

Based on the results of data analysis, several conclusions can be drawn: (1) There is an effect of work motivation on teacher performance. This means that the higher the teacher's work motivation, the teacher's performance will increase; (2) There is an effect of work discipline on teacher performance. This means that the higher the work discipline, the higher the teacher's performance; (3) There is an influence of work motivation and work discipline on teacher performance. Thus, work motivation and work discipline can affect teacher performance. Work motivation and work discipline can affect teacher performance with a contribution of $71.5 \%$ while the remaining $28.5 \%$ is explained by factors not examined in this study.

Based on the findings and conclusions above, several recommendations that be suggested are as follows: (1) Principals should take steps that are able to increase the motivation and work discipline of teachers in each school. First, the application of the teacher's presence system that uses a finger print so that attendance cannot be represented and manipulated because it is systemically integrated, so that authentic data will be obtained related to attendance which can be used as an aspect of teacher discipline assessment. The presence aspect of a wellintegrated attendance data can represent how the situation of each individual is. Because with the obedience to be on time, it can be used as a reflection that someone has high responsibility and dedication to a given task or mandate. (2) When viewed carefully from motivation and work discipline, it is possible that these two things are elements that function to shape teacher performance in carrying out their duties as a teacher. It is better if a teacher always has motivation and discipline to work consciously without any coercion from anyone in order to create a professional teacher. Thus the encouragement and enthusiasm in a teacher to excel will be realized if supported by good teaching skills. Teaching ability can be seen as a general characteristic of a person related to knowledge and skills that are manifested through action.

\section{REFERENCES}

[1] Septiana, R. N. (2013). Pengaruh Kepemimpinan Kepala Sekolah dan Motivasi Kerja terhadap Kinerja Guru SMP Negeri Wonosari. Jurnal Pendidikan UNS, 107-118.

[2] Undang-Undang Republik Indonesia Nomor 14 Tahun 2005 Tentang Guru dan Dosen. Jakarta.

[3] Damayani, T., Arafat, Y., \& Eddy, S. (2020). Pengaruh Kepemimpinan Kepala Sekolah dan Motivasi Kerja terhadap Kinerja . Journal of Innovation in Teaching and Instructional Media, 1(1), 46-57. Retrieved from https://ejournal.karinosseff.org/index.php/jitim /article/view/29

[4] Husna, N. (2017). Pengaruh Disiplin Kerja Terhadap Kinerja Guru Pada SMAN 1 Canduang Kabupaten Agam. Jurnal Ekobistek Fakultas Ekonomi, Hal. 286-298. 
[5] Setiyati, S. (2014). Pengaruh Kepemimpinan Kepala Sekolah, Motivasi Kerja, dan Budaya Sekolah terhadap Kinerja Guru. Jurnal Pendidikan Teknologi dan Kejuruan, 200-207.

[6] Nasution. (2010). Berbagai Pendekatan dalam Proses Belajar \& Mengajar. Jakarta: Bumi Aksara.

[7] Supardi. (2014). Kinerja guru. Jakarta: PT Raja Grafindo Persada.

[8] Rivayanti, Arafat, Y., \& Puspita, Y. (2020). Manajemen Kepemimpinan Kepala Sekolah dalam Pembinaan Profesionalisme Guru . Journal of Innovation in Teaching and Instructional Media,1(1), 10-17. Retrieved from

https://ejournal.karinosseff.org/index.php/jitim /article/view/25

[9] Sujadi, E., Fadhli, M., Kamil, D., Ds, M. R., Sonafist, Y., Meditamar, M. O., \& Ahmad, B. An anxiety analysis of educators, students and parents facing the new normal era in education sector in indonesia. Asian journal of psychiatry, 53, 102226.

[10] Setio Handhini, L., Ahmad, S. ., \& Wahidy, A. (2020). Pengaruh Supervisi Akademik Kepala
Sekolah dan Budaya Sekolah Terhadap Mutu Mengajar Guru. Journal of Innovation in Teaching and Instructional Media, 1(1), 90103. Retrieved from https://ejournal.karinosseff.org/index.php/jitim /article/view/35

[11] Wahjosumidjo. (1987). Kepemimpinan dan Motivasi. Jakarta: Ghalia Indonesia.

[12] Husna, N. (2017). Pengaruh Disiplin Kerja Terhadap Kinerja Guru Pada SMAN 1 Canduang Kabupaten Agam. Jurnal Ekobistek Fakultas Ekonomi, Hal. 286-298.

[13] Sugiyono. (2010). Metode Penelitian Pendidikan Pendekatan Kuantitatif, kualitatif, dan $R \& D$. Bandung: Alfabeta.

[14] Sugiyono. (2011). Metode penelitian kuantitatif kualitatif dan $R \& D$.alfabeta

[15] Arikunto. (2006). Metode random memberikan hak yang sama kepada semua guru sebagai subjek dalam populasi untuk memperolah kesempatan dipilih menjadi sampel penelitian. Jakarta: Rineka Cipta. 